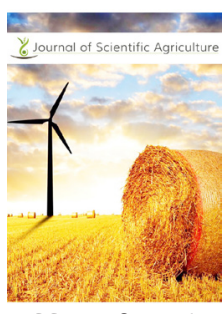

ISSN: $2184^{-0261}$

Received: April 02, 2019

Accepted: May 17, 2019

Published: May 21, 2019

Corresponding author: Md. Niuz Morshed Khan E-mail: rumman899@gmail. com

\section{Studies on in vitro response to callus induction and gene transfer technique of five high yielding indica rice varieties}

\author{
Md. Niuz Morshed Khan*, Md. Monirul Islam², Md. Shahidul Islam', \\ Md. Imtiaz Uddin²
}

'Deparment of Bioetechnology, Bangladesh Agricultural University, Mymensingh 2202, Bangladesh, ${ }^{2}$ Biotechnology Division, Bangladesh Institute of Nuclear Agriculture (BINA), Mymensingh 2202, Bangladesh

\begin{abstract}
In this study embryogenic calli from mature seeds of five indica rice varieties viz. Binadhan-5, Binadhan-6, BRRI dhan48, BRRI dhan-58 and IR-64 were observed that is done in four different concentration of growth regulators $(2,4-D)$. The highest callus induction were observed in media containing $2 \mathrm{mg} / \mathrm{L}$ 2,4-D. Among those varieties BRRI dhan-48 showed highest rate of callus induction (48.92\%). In this experiment Agrobacterium mediated genetic transformation of OsCAL gene into indica rice was also tried. Although some green plants were found but plantlets were not confirmed either by molecular tests or desired phenotypic characteristics. This study will be useful for selecting suitable callus induction medium for callus induction in future.
\end{abstract}

KEYWORDS: Callus induction, agrobacterium mediated gene transfer, embryogenic callus, 2,4-D

\section{INTRODUCTION}

Rice (Oryza sativa L.) a monocot plant comprised two subspecies, Indica and Japonica [1]. It is being cultivated for more than 10,000 years [2]. Out of the all crops that are using as feed in all over the world rice provide $23 \%$ of the calories consumed by the whole population [3]. Indica rice encompasses $80 \%$ of the world rice cultivation [4] and this types of rice is mainly grown in South and South-East Asian countries of the world [5].

Rice is the staple food of larger than half of the population of the world [6] serves more than 90\% Asian population and is occupy the second position among the cultivated cereal in the world, after wheat [7]. For coping with the everincreasing population of the world the total rice production has to be amplified 50\% within 2025 [8]. This goal cannot be accomplished by increasing the cultivation area under rice cultivation because of the unavailability of proper lands. On the other hands the farm areas are being limited by residential areas in the developing countries. The most possible solution of this problem is to increase the productivity of rice which can be done by developing new genotypes tolerant to biotic and abiotic stresses with high yielding capacity. Previous experiments showed that the production rate of rice is unpleasantly affected by abiotic stress and that is highly defenseless with the change of weather $[9,10,11,12]$. Genetic transformation is the technique that enables the introduction of novel genes [13].

Various tools of Modern biotechnology including genetic transformation enable rice breeders to fight against this types of problems. In fact, different considerable efforts were made for the genetic improvement of various rice varieties throughout the last two decades in the world [14]. Therefore, before applying transformation methods optimization of an efficient regeneration protocol for specific cultivar(s) is an essential for this the composition of the nutrient media (basal salts, organic components, and growth regulators) is a major factor that influencing the rate of frequency of rice regeneration [15]

Agrobacterium-mediated transformation of rice (Oryza sativa) is a technique that is depends on tissue culture and the primary and main step of tissue culture is callus initiation [16]. Indica rice varieties are often considered as recalcitrant regarding the induction of callus $[17,18,19]$.

In this experiment we tried to optimize the rate of growth regulators (2,4-D) for callus induction and efficient genetic 
transformation protocol of indica rice using Agrobacterium tumefaciens as a vector.

\section{MATERIALS AND METHODS}

\section{Experimental Materials}

The experiments were carried out during the period from April, 2018 to November, 2018 at the Tissue culture Laboratory, Biotechnology Division Bangladesh Institute of Nuclear Agriculture (BINA), Mymensingh. Mature seeds of five indica rice (Oryza sativa L.) such as Binadhan-5, Binadhan-6, BRRI dhan 48, BRRI dhan 58, and IR 64 were used as experimental material to study different parameters associated with callus induction of plant. In this experiment we used a super-virulent Agrobacterium GV3101 strain harbouring plant expression vector pB2WG7 containing OsCAL (Calmodulin like protein) genes. This binary vector contains following genes within the right border $(\mathrm{RB})$ and left border (LB) region of the construct.

\section{Surface Sterilization of Seeds}

Seeds were surface sterilized by dipping near 1 minute in $70 \%$ ethyl alcohol with vigorous shaking, then it was washed 5 to 6 times with distilled water. After washing Surface disinfection was done by using of $50 \% \mathrm{NaOCl}$ with 1 drop Tween-20 for 15 minutes at $300 \mathrm{rpm}$ in a shaker. Then the seeds were subsequently washed 7 to 10 times with sterile distilled water to remove traces of sterilant that would be toxic to the seed materials if kept for longer duration. The surface sterilized seeds were then dried for 5-6 min on a sterilized filter paper.

\section{Callus Induction}

Sterilized seeds were cultured directly in MS medium supplemented with different concentration of growth regulators required as per treatment. In this experiment we used four different concentration of growth regulators $(1 \mathrm{mg} / \mathrm{L}, 1.5 \mathrm{mg} / \mathrm{L}$, $2 \mathrm{mg} / \mathrm{L}$ and $2.5 \mathrm{mg} / \mathrm{L} \mathrm{2,4-D).} \mathrm{The} \mathrm{culture} \mathrm{media} \mathrm{and} \mathrm{all} \mathrm{the}$ glass wares were autoclaved at $1.16 \mathrm{kgcm}^{-2}$ pressure and $121^{\circ} \mathrm{C}$ temperature for 30 minutes. The following Equation was used for determining the callus induction frequency as given below.

$$
\text { percent }(\%) \text { callus induction }=\frac{\begin{array}{c}
\text { Number of callus } \\
\text { induction }
\end{array}}{\begin{array}{c}
\text { Number of seeds } \\
\text { incubated }
\end{array}} \times 100
$$

Percent of embryogenic callus were calculated on the basis of the number of induced callus and the total number of embryogenic callus.

$$
\text { Percent }(\%) \text { of embryogenic callus }=\frac{\begin{array}{c}
\text { Number of } \\
\text { embryogenic callus }
\end{array}}{\begin{array}{c}
\text { Number of } \\
\text { callus induction }
\end{array}} \times 100
$$

\section{Subculture}

Callus was formed within 6-7 days. After 14 days the nonembryogenic calli were discarded and only the calli that are embryogenic were selected for subculture. The root and shoot are discarded and only the embryogenic calli are transferred to new medium containing the same composition of callus induction medium.

\section{Infection and Co Cultivation}

Prior to co cultivation the cultured Agrobacterium in LB medium was separated by centrifugation for 10 minutes at $3200 \mathrm{~g}$ and $20^{\circ} \mathrm{C}$ temperature, the pellet was dissolved in same amount of AA-AS media completely by vortexing. Then all the embryogenic calli were infected by immersing them in the mixed culture for 15-20 minutes with intermittent gentle shaking at $50 \mathrm{rpm}$. The infected calli were then dried on sterile whatman filter paper for 5 minutes. Then the infected calli were transferred to the co cultivation medium containing $10 \mathrm{~g} / \mathrm{L}$ glucose and $150 \mu \mathrm{M}$ acetosyringone at $\mathrm{P}^{\mathrm{H}} 5.8$ and incubated at $27 \pm 1^{\circ} \mathrm{C}$ in the dark for 48 hours.

\section{Selection}

After co cultivation the infected calli with slight growth of Agrobacterium were rinsed 5-6 times with $250 \mathrm{mg} / \mathrm{L}$ cefotaxime and $200 \mathrm{mg} / \mathrm{L}$ timentin in sterile distilled water respectively. The calli were then dried on sterile whatman filter paper for 5 minutes and transferred onto selection medium containing $250 \mathrm{mg} / \mathrm{L}$ cefotaxime and $50 \mathrm{mg} / \mathrm{L}$ streptomycin and incubated for 12 days at $27 \pm 1^{\circ} \mathrm{C}$ in dark. This step is repeated for 3 times (10 \& 15 days).

\section{Regeneration of Transformed Calli}

After third selection, black or brown microcalli were discarded and only granular 'macrocalli' were transferred onto regeneration media containing either two or three growth regulators comprised of MS salts, $30 \mathrm{~g} / \mathrm{l}$ maltose, $2 \mathrm{mg} / \mathrm{l}$ kinetin, $0.2 \mathrm{mg} / \mathrm{l}$ naphthalene acetic acid (NAA), $\mathrm{P}^{\mathrm{H}} 5.8 ; 250 \mathrm{mg} / \mathrm{l}$ cefotaxime and $30 \mathrm{mg} / \mathrm{l}$ streptomycin added after autoclaving. The media was supplemented with $10 \mathrm{~g} / \mathrm{l}$ agar during regeneration. These microcalli were incubated at $27 \pm 1^{\circ} \mathrm{C}$ in dark for 7 days for the first phase of regeneration. Then these microcalli were transferred to fresh regeneration medium and incubated in light at $27 \pm 1^{\circ} \mathrm{C}$ temperature.

\section{RESULTS AND DISCUSSION}

Plant regeneration is a system that is essential for establishing an efficient application of biotechnology that can be utilized for crop improvement in future. By using mature seeds somatic embryogenesis has been proved to be more reliable method of obtaining true type plant. Therefore, in vitro regeneration from induced callus from mature embryos of five indica rice (Oryza sativa $\mathrm{L}$.) varieties was investigated in this study. Results of different steps of the experiments are described under the following heads. 


\section{Callus Induction}

The first step of this experiment was callus induction from mature seeds. To meet this purpose, callus induction potentiality of mature embryo on different MS media supplemented with different concentrations of growth regulators was investigated.

Embryo of mature seeds of five varieties of rice used as explants were cultured on MS media supplemented with four different concentrations of 2,4-D (1.0, 1.5, 2.0 and 2.5) for callus induction. Callus induction performances of all the varieties in each treatment were evaluated and presented in Table-2 \& Figure-1.

Callus initiation started from six days of incubation and took about fourteen to sixteen days for the completion followed by Binadhan-5, Binadhan-6, BRRI dhan-48, BRRI dhan-58 and IR-64 respectively (Figure-1 and Figure-2). The percentage of callus induction was highest in BRRI dhan-48 (48.92\%), followed by Binadhan-6 (43.08\%), and lowest in BRRI dhan$58(24.92 \%)$. (Table 2$)$.

\section{Effects of Growth Regulator Treatments On Callus Induction}

Different concentration of growth regulators showed variation on the percentages of callus induction and embryogenic callus. Mean square value of those treatments are statistically significant. For the percentages of callus induction and embryogenic callus. Among those treatments of growth regulators $2 \mathrm{mg} / \mathrm{L} \mathrm{2,4-D}$ was found to be the best of all variety (Table 1 ).

$2 \mathrm{mg} / \mathrm{L} 2,4-\mathrm{D}$ showed the highest percentage (71.46\%) of callus induction followed by $1 \mathrm{mg} / \mathrm{L} 25.13 \%, 1.5 \mathrm{mg} 24.26 \%$ and lowest $(24.20 \%)$ percentage of callus induction was observed in $2.5 \mathrm{mg} / \mathrm{L} 2,4-\mathrm{D}$ concentration. $2 \mathrm{mg} / \mathrm{L} \mathrm{2,4-D}$ showed the highest percentage 57.33 of embryogenic callus production and lowest $7.00 \%$ of embryogenic callus was produced when $2.5 \mathrm{mg} / \mathrm{L} 2,4-\mathrm{D}$ was used.

The findings of our study were in agreement with the previous works [20, 21, 22, 23, 24]. In our study $2 \mathrm{mg} / \mathrm{L}$ 2,4-D showed highest rate of callus induction. Similar observations were also reported in rice by Verma [23] where they showed that different varieties of rice produced high amount of callus cultured on MS medium supplemented with $2.0 \mathrm{mg} / \mathrm{l}$ 2, 4-D.

Table 1: Effects of different 2,4-D concentration on callus induction

\begin{tabular}{lc}
\hline Treatments combination & Percent of callus induction \\
\hline $1.0 \mathrm{mg} / \mathrm{L} \mathrm{2,4-D}\left(\mathrm{T}_{1}\right)$ & $25.13333 \mathrm{~b}$ \\
$1.5 \mathrm{mg} / \mathrm{L} \mathrm{2,4-D}\left(\mathrm{T}_{2}\right)$ & $24.26667 \mathrm{~b}$ \\
$2.0 \mathrm{mg} / \mathrm{L} \mathrm{2,4-D}\left(\mathrm{T}_{3}\right)$ & $71.46667 \mathrm{a}$ \\
$2.5 \mathrm{mg} / \mathrm{L} \mathrm{2,4-D}\left(\mathrm{T}_{4}\right)$ & $24.20000 \mathrm{~b}$ \\
$\mathrm{CV}(\%)$ & 23.38879 \\
$\mathrm{LSD}(0.05)$ & 6.259898 \\
\hline
\end{tabular}

In the column figures followed by same same letter (s) in a do not statistically significant

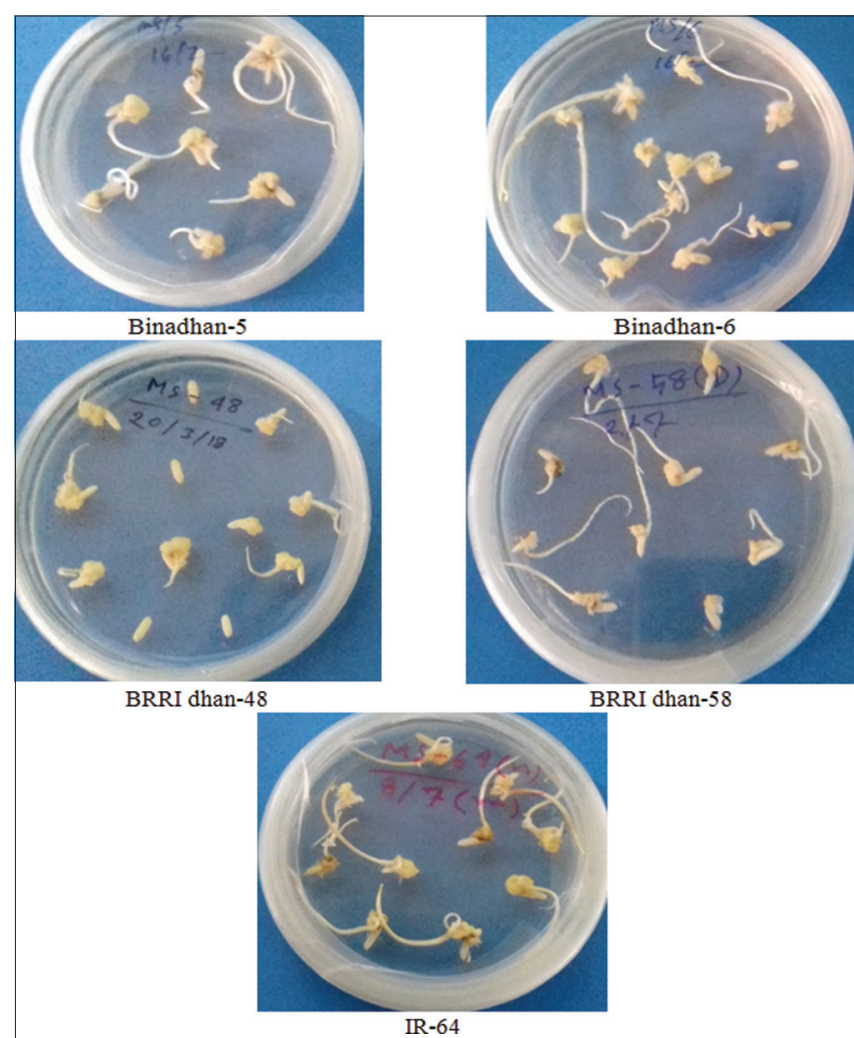

Figure 1: Callus induction from mature embryos of five indica rice varieties
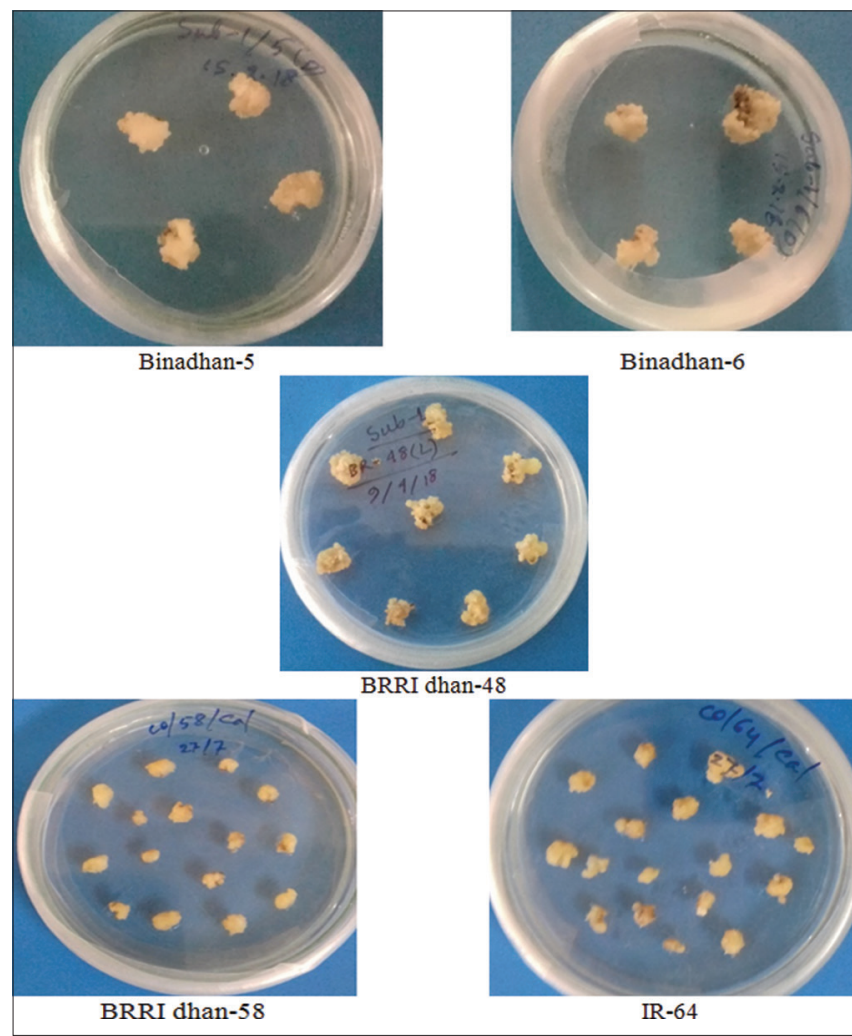

Figure 2: Callus of five indica rice varieties from mature embryos after subculture 
Table 2: Varietal differences in callus induction (2 mg/l, 2,4-D)

\begin{tabular}{lc}
\hline Variety & Percent of callus induction \\
\hline Binadhan-5 & $32.08333 \mathrm{~b}$ \\
Binadhan-6 & $43.08333 \mathrm{a}$ \\
BRRI dhan-48 & $48.91667 \mathrm{a}$ \\
BRRI dhan-58 & $24.91667 \mathrm{c}$ \\
IR-64 & $32.33333 \mathrm{~b}$ \\
CV (\%) & 23.38879 \\
LSD (0.05) & 6.998779 \\
\hline
\end{tabular}

In the column figures followed by same same letter (s) in a do not statistically significant

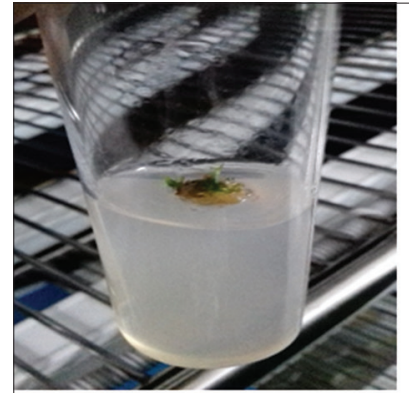

a) After 7 days of inoculation

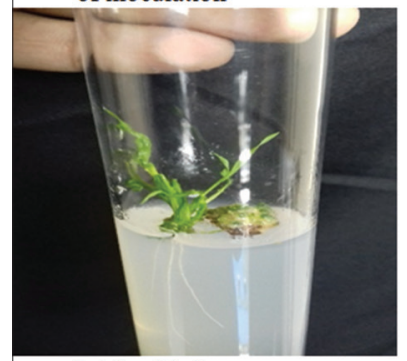

c) After 21 days

of inoculation

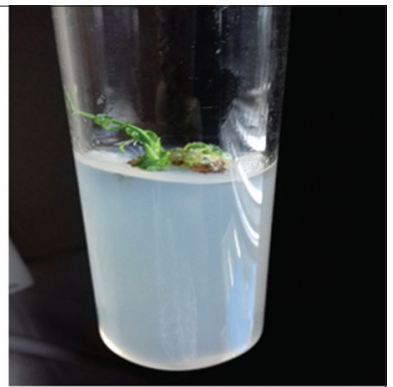

b) After 14 days of inoculation

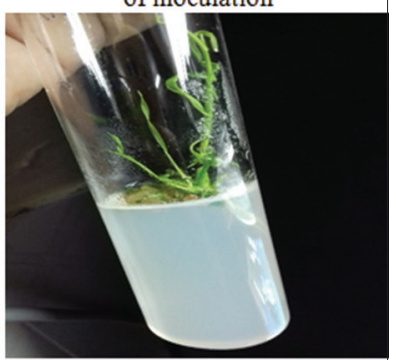

d) After 25 days of inoculation
Figure 3: Regeneration from transformed calli

\section{Effects of Different Varieties on Callus Characters for Growth Regulators Treatment}

The genotypic mean square values of rice were found statistically significant for all the characters of callus induction such as percent of callus induction and percent of embryogenic callus under those treatment (Table 2).

Highest (48.92\%) percentage of callus induction was observed in BRRI dhan-48 closely followed by Binadhan-6 (43.08\%), IR-64 (32.33), Binadhan-5 (32.08) and lowest (24.92\%) in BRRI dhan-58. Which were statistically significant. Percentage of embryogenic callus was higher $(34.67 \%)$ in BRRI dhan48 followed by Binadhan-6 (23.83\%), IR-64 (17.83\%), Binadhan-5 (15.17\%) and lowest (12.42\%) in BRRI dhan-58 which were statistically significant.

\section{Regeneration of Transformed Embryogenic Calli}

Among 5 indica rice varieties we got plantlets from IR-64 and it required almost 25 days for plantlet regeneration from transformed calli (Figure 3).

\section{Agrobacterium-mediated Genetic Transformation}

The callus which survived in selection medium containing antibiotic (cefotaxime and timentin) may be transformed callus. We got plantlets from those calli after third selection (Figure 3) so initially we can select them as transgenic plants but were not confirmed either by molecular tests or others.

\section{CONCLUSION}

In this experiment a thorough investigation was carried out for knowing the calli induction ability and Agrobacterium mediated genetic transformation technique of five indica rice varieties named Binadhan-5, Binadhan-6, BRRI dhan 48, BRRI dhan 58 , IR-64. Though we identified medium composition for successful calli induction of indica rice and obtained plantlets following Agrobacterium- mediated transformation of calmodulin like protein coding genes (OsCAL) into the indica rice, we need to repeat the transformation protocol and test the transformants with different molecular techniques.

Although plants were found, used to be tested continued by molecular methods and tested the desired characters for selecting those plantlets as transgenic plant.

\section{ACKNOWLEDGMENTS}

Thanks to Bangladesh Institute of Nuclear Agriculture (BINA), Bangladesh for all experimental support. The authors would also like to thank the reviewers for their comments on the manuscript.

\section{AUTHOR CONTRIBUTION}

MNMK performed laboratory work, MMI provided all kind of supports including techniques development, providing chemicals and equipment etc MIU provided the gene (OsCAL). MMI and MSIsupervised work and helped prepare the manuscript.

\section{REFERENCES}

1. Vaughan DA, Morishima H, Kadowaki K. Diversity in the Oryza genus. Current opinion in plant biology. 2003;6:139-146.

2. Sasaki T. Rice genome analysis to understand the rice plant as an assembly of genetic codes. Photosynthesis research. 2001; 70;119-127.

3. Khush GS, Virk PS. Rice Breeding: Achievement and future strategies Crop Improvement. 2001;27:115-144.

4. Tie W, Zhou F, Wang L, Xie W, Chen H, Li X, Lin Y. Reasons for lower transformation efficiency in indica rice using Agrobacterium tumefaciens-mediated transformation: lessons from transformation assays and genome-wide expression profiling. Plant molecular biology. 2012;78:1-18.

5. YaqoobPU, JanPB, KaulPT, NawchooP IA. Tissue culture of rice: Problems, progress and prospects. IJISET. 2016;3:581-613.

6. Hadiarto T, Tran LSP. Progress studies of drought-responsive genes in rice. Plant cell reports. 2011;30:297-310.

7. Pazuki A, Sohani MM. Phenotypic evaluation of scutellum-derived calluses in 'Indica'rice cultivars. Acta agriculturae Slovenica. 2013: 101:239-47.

8. Khush GS, Virk PS. Rice breeding: achievements and future 
strategies. Crop improvement. 2000;27:115-144.

9. Binte Mostafiz S, Wagiran A. Efficient Callus Induction and Regeneration in Selected Indica Rice. Agronomy. 2018;8:77.

10. Bzour MI, Zuki FM, Mispan MS. Introduction of imidazolinone herbicide and Clearfield ${ }^{\circledR}$ rice between weedy rice-Control efficiency and environmental concerns. Environmental Reviews. 2018;26:181-198.

11. Zulkarnain WM, Ismail MR, Saud HM, Othman R, Habib SH, Kausar H. Growth and yield response to water availability at different growth stages of rice. Journal of Food, Agriculture \& Environment. 2013;11:540-544.

12. Azmi M, Azlan S, Yim KM, George TV, Chew SE. Control of weedy rice in direct-seeded rice using the Clearfield production system in Malaysia. Pak J Weed Sci Res. 2012;18:49-53.

13. Roly ZY, Islam MM, Shaekh MPE, Arman MSI, Shahik SM, Das D, Haamem MME, Khalekuzzaman M. In vitro callus induction and regeneration potentiality of aromatic rice cultivers (Oryza sativa L.) in differential growth regulators. Int. J. Applied Sci. \& Biot. 2014;2:160-167.

14. Sripriya R, Parameswari C, Veluthambi K. Enhancement of sheath blight tolerance in transgenic rice by combined expression of tobacco osmotin (ap24) and rice chitinase (chi11) genes. In Vitro Cellular \& Developmental Biology-Plant. 2017;53:12-21.

15. Amer AM, Mohamed GM, Hussein MH, Sedik MZ, Aly, UI. Effect of some of the natural organic sources on rice tissue culture. Egyptian Pharmaceutical Journal. 2017:16:152.

16. Walden R, Wingender R. Gene-transfer and plant-regeneration (techniques). Trends in biotechnology. 1995;13:324-331.
17. Dong JJ, Kharb P, Teng WM, Hall TC. Characterization of rice transformed via an Agrobacterium-mediated approach. Mol. Breed. 2001;7:187-194.

18. Hiei Y, Ohta S, Komari T, Kumashiro T. Efficient transformation of rice (Oryza sativa L.) mediated by Agrobacterium and sequence analysis of the boundaries of the T-DNA. The Plant Journal. 1994;6:271-282.

19. Hiei Y, Komari T. Agrobacterium-mediated transformation of rice using immature embryos or calli induced from mature seed. Nature Protocols. 2008;3:824.

20. Libin A, King PJH, Ong KH, Chubo JK, Sipen P. Callus induction and plant regeneration of Sarawak rice (Oryza sativa L.) variety Biris. Afr. J. Agric. Res. 2012;7:4260-4265.

21. Abiri R, Maziah M, Shaharuddin NA, Yusof ZNB, Atabaki N, Hanafi MM, Sahebi M, Azizi P, Kalhori N, Valdiani A. Enhancing somatic embryogenesis of Malaysian rice cultivar MR219 using adjuvant materials in a high-efficiency protocol. International Journal of Environmental Science and Technology. 2017;14:1091-1108.

22. Alam MJ, Imran M, Hassan L, Rubel MH, Shamsuddoha M. In vitro regeneration of high yielding indica rice (Oryza sativa L.) varieties. Journal of Environmental Science and Natural Resources. 2012; 5:173-177.

23. Verma D, Joshi R, Shukla A, Kumar P. Protocol for in vitro somatic embryogenesis and regeneration of rice (Oryza sativa L.). 2011.

24. Mannan MA, Sarker TC, Akter MT, Kabir AH, Alam, MF. Indirect plant regeneration in aromatic rice (Oryza sativa L.) var. 'Kalijira'and 'Chinigura. Acta. Agric. Slovenica. 2013; 101:231. 